\title{
A Qualitative Study on Increasing Divorce Rates at the Khulna City of Bangladesh
}

\author{
Musammat Mahzebin \\ Lecturer (Sociology), Department of humanities, Khulna University of Engineering and Technology, \\ Bangladesh (KUET)
}

\begin{abstract}
Divorce or separation is a personal as well as social issue. As a result of divorce, a bride has to come back to her parents' house which is not considered respectable in the society of Bangladesh. And the situation can be more difficult if the parents are not alive or have no property. The study mainly focused on the causes and consequences of increasing divorce rate among urban women. For this purpose, women from 26 no. and 31 no. Ward of Khulna City Corporation area under Khulna District was purposively selected as the study area. This study is descriptive in nature, case study and focus group discussion method was used to conduct the study. Qualitative data were collected from the respondents who are separated from husband at least two years using a FGD guide. Total 26 samples were selected following the quota sampling method and every group contains 13 members on the basis of employment. The reason for divorce is multidimensional for women. Studies have revealed many traditional causes of divorce such as dowry, failure in the role of husband's provider, presence of alcohol and drug addiction, infertility, sexual dysfunction and physical violence. In addition, many modern reasons for divorce such as conflict of values, lack of commitments of the husband, suspicious nature of the husband, extramarital affairs and mental abuse can be the cause of divorce. After divorce, women face financial crisis, social harassment by family and society. Children from broken family are victim to psychological problem as well as economic crisis. Divorce always not a solution of conjugal life Problem. The marital life survives on the self-sacrifice of both wife and husband. The couple who learns to sacrifice to each other will be able to enjoy a beautiful life.
\end{abstract}

Keywords: Divorce, Marriage.

DOI: $10.7176 /$ RHSS/11-22-03

Publication date: November $30^{\text {th }} 2021$

\section{Introduction}

Family and marriage, as a social institution, have been around for almost a thousand years. (Akter, 2013.). Family is the essential unit of life that gives safety and comfort to their members (Alam,et.el. 2001).Marriage is socially and legally allowed union (Afroz, 2019.). It is governed by the laws, beliefs and attitudes of society (Khanom, 2017) which creates strong family bond (Afroz, 2019). But developments since the middle of the twentieth century show that this idea is wrong. (Afroz, 2019). In many countries, marriage is declining, people are getting married later, divorce or break down of family loosen the role of family and marriage (Monsor, 2003). Women empowerment, education, participation of economic sector, decision making right, violent against women, ignorance of husband, domestic violence etc. Increase the divorce rate (Patoari, 2020). In addition, the COVID19 pandemic presented unprecedented challenges to many couples (Nowsen, 2021.). Overcoming the often-fatal effects of the disease, many couples also lose their jobs (particularly women), lots of stress as a result of parenting children through distance education and similarly reduced sexual drive (Huda, 2021). According to Matt Lundquist, Clinical Director of Tribeca Therapy, the epidemic has created an existing maelstrom, which in most cases couples have previously ignored or tried to ignore (Nowsen, 2021). Despite the fact that the marriage rate is declining faster than the divorce rate, experts predict that between 40 and $50 \%$ of all existing marriages will eventually end in divorce (AFS, April, 2021).

Divorce applications and break-ups were found to be skyrocketing across the U.K. The same is true in Sweden as well as in Italy (Huda, 2021). Divorce rate has also increased in Dhaka, Bangladesh during the Covid-19 Period (AFS, April, 2021). $30 \%$ divorce rate has grown from last year during June to October in 2020 (BBS, 2021). There are 39 divorces every day in the capital or one divorce every 37 minutes for five months from June (BBS,2021). From June to October 2020, 5,970 divorces were completed (BBS,2021). Chattogram follows 18 divorces a day but in Sylhet the submission of divorce appeal has gone up 10 times higher in the first 10 months of this year (BBS, 2021). Crude divorce rate in Khulna is 1.4 where crude marriage rate is 17.1 and divorce marriage ratio is 0.08 percent (BBS, 2021). Divorce rates have received considerable attention in many developed countries because of its enchanting influence on individuals and society. In our country it has become a matter of concern. Recent studies have shown women initiated divorce from the perspective of women's experience.

\section{Material and Methods}

The study is descriptive in nature. It is a result of data collection from the divorced women belonging age 25 to 55, living 26 no. ward and 31 no. Ward of Khulna City Corporation area of Bangladesh during April 2021 to June 
2021. In-depth interview are the key source of qualitative data about the causes and consequences of divorce. Through in depth interview of the divorced women provide the data of major reasons, problems, expectations of their life. Two FGD (Focus Group Discussion) have been done to identify the common problems they are facing and three Case Studies have been conducted to visualize existing problem associated with Covid-19 situation. For this purpose, the study design was covered the contents such as population, sample size, sample selection procedure. The study design also focus on field investigation for primary data collection through a Check List, FGD and informal conversation; Sources of secondary data which used from relevant sources for the better understanding of the problem. To achieve the objectives, some specification was made. Data were collected from divorced women of selected area were identified as the unit of analysis and the population of the study was all divorced women in Khulna City Corporation area. Total 26 samples were selected for FGD following the Quota Sampling Method where every group contains 13 equally on the basis of employment and unemployment.

Table is drown below to show the procedure-

Table 1: Sampling Procedure

\begin{tabular}{|c|c|c|}
\hline Population Category & Method of Sampling & Size of the Sample \\
\hline $\begin{array}{c}\text { Population-1 } \\
\text { (Employed Women) }\end{array}$ & Quota Sampling Method & 13 \\
\hline $\begin{array}{c}\text { Population-2 } \\
\text { (Unemployed women ) }\end{array}$ & Quota Sampling Method & 13 \\
\hline
\end{tabular}

\section{Findings and Discussion}

This chapter investigates the reasons behind increasing divorce problem of women during Covid- 19 pandemic in 26 and 31 no. ward of Khulna City Corporation area of Bangladesh. For this purpose, data were collected from six women through case studies and in-depth interviews. Two FGD were conducted to know the overall condition of the divorced women.

\section{Scenario of Divorce in Bangladesh}

Divorce is a right that women or men can exercise on certain grounds under the law. In present any man or woman in Bangladesh can exercise this right without any hindrance and sometimes it is practiced on weak ground and no one can legally prevent him from exercising this right. An application for divorce in every hour is being submitted to the City Corporation. According to statistics, in the first 180 days of 2019, there were 4500 divorce applications were filed (BBS, 2020). A survey shows that from 2010 to 2019, the number of divorces in the capital was around 70,000 and 50 to 60 divorce applications were filed daily (BBS, 2020). In just five months from June to October 2020, the divorce rate has increase by 29.78 percent (BBS, 2021). During this pandemic situation, most of the people fall in lower income and many lost their job. These unstable economic conditions also impact their family life. 38 divorces have been completed in everyday during January to August 2021.99 divorces have increased in every month from last year. Information from two City Corporation, 75 percent divorce is taking by women. In the last year 70 percent divorce also took by women. In only two city corporations in Dhaka, the number of divorce applications is very worrying and alarming. Sociologists think economic crisis and mental pressure created by Covid-19 pandemic are major cause to increasing family conflict and divorce rate in Bangladesh (). Besides this mutual respect, conflict of personality between husband and wife are also a salient cause of increasing divorce rate. Growing ferociousness against women during this Covid period is responsible for divorce from women's side.

Going back to the BBS findings, in two city corporations of Dhaka and Chattogram City Corporation, most of the applications were filed by women.

Although the most common causes of divorce have been found to be marital conflict during COVID situation. The most common reasons of divorce for women were their husbands' suspicious nature, extramarital affairs, demand dowry, husbands not returning home after going abroad, drug addiction, Facebook addiction, incapability and personality breakdown.

\section{Causes of Increasing Divorce in Bangladesh by Women}

Divorce is the only way to legally end a marital relationship that both parties can apply for on a specific basis. In Bangladesh, divorce is a right that can be exercised by either party. The various reasons for the increase in divorce in Bangladesh by women are discussed below:

\subsection{Age of marriage}

Generally age of marriage of women is sixteen to twenty. The age gap between husband and wife also high. Women claim that distance of age between them creates mental and emotional crisis.

Moreover, the prevalence of child marriage in Bangladesh presents an unfortunate paradox: on the one hand, girls under the age of 15 (even younger) are being forced into marriage. On the other hand, more women seem to be choosing to leave their marriages of their own will. Sometimes they said: 
At present they think their age distance make emotional disharmony and husband cannot understand their emotional need.

\subsection{Mutual Respect}

Findings from in-depth study as well as face to face interview provide us very distinct information about divorced women. Trust, love and mutual respect between husband and wife are getting lost day by day which is one of the main reasons for divorce.

\subsection{Physical and Mental Torture for Demanding Dowry}

One of the main reasons for divorce in Bangladesh by women is physical and mental torture by husband and other members of the husband's family for demanding dowry to the wife's family. Sometimes women commit suicide due to unbearable suffering. Dowry system is a social disorder in Bangladesh. Women are subjected to various violations for dowry

They said:

We are tortured by husband and their family for dowry. Our parents failed to pay dowry during marriage even after few years of marriage. Most of the time husband and their family start to torture physically and mentally.

When the victim has no other chance to free herself from the curse of dowry, she decides to divorce her husband.

\subsection{Husband's Drug Addiction and Physical Torture}

Another reason for divorce in Bangladesh by women is the drug addiction of the husband and the physical abuse of the wife by the husband. Loss of job, frustration, economic crisis due to pandemic situation most of the people engaged in informal sector are become drug addicted. Most of the women working outside home are also lost their job. They feel house is more insecure because their husband are drug addicted and they tortured physically. One respondent expressed:

It is impossible to adjust with their husband when both are jobless .Poor income frustrated their husband and make drug addicted and tortured them physically anytime.

\subsection{Extramarital Relationship}

Another significant cause of divorce by women in Bangladesh is to engage extramarital relationship of their husband with other women. Illegal relationships provoke both wife and husband to hasten the end of a marital relationship. They think husband relation to others women is not considerable. There are various reasons for extramarital affairs in Bangladesh.

One respondent said: Dissatisfaction with sexual desire and lack of self-control are common causes of extramarital affairs.

\subsection{Marriage under pressure}

Sometimes people are forced to agree to the marriage due to family and society's pressures or sometimes the parties agree to the marriage by blackmailing by their own family members. As a result it has been created a gap between the two partners from the very beginning of their married life. If this gap continues for the long time, it creates a void in the partners and people look for extramarital affairs to fill the void.

\subsection{Financial establishment and Career Development}

Nowadays career development and financial establishment is one of the main reasons for increasing divorce by women. Day by day women are involving various jobs especially in the private sector.

They give more importance their career and financial development rather than family. Due to pandemic situation, most of the women involved in private sector are lost their job. They feel inferiority complex and sometimes rebuked by husband.

They still practices inter-cast marriage. But professional importance is losing day by day. They want to hand -over their daughter with an educated person but must be inter-caste. Pon or dowry system is still existing which are not reduce through consciousness or education. Still they prefer to give and take cash money and gold from both bride and groom side. One respondent whose three daughters have been already married is said:

It is impossible to tolerate my husband's rebuking and quarreling everyday when I lost my job. So taking the decision of divorce is then emergency need to my life. Bad temper, suspicion, self ego, indifference, impatience are the reasons for breaking up the family.

My three daughters were completing graduation and their husband also well-educated. But they took more than 5 lakh T.K. BDT things and cash and she gave it her every daughter's marriage. It is compulsory for bride's parents if they wealthy or not. 


\subsection{Conflict in family and the suspicious nature of the husband}

Conflict in Family directly influences on women to divorce their husbands. Present day women are being educated and aware of their various rights and they are not willing to continue their married life in a dissatisfied environment.

Regular family conflicts darken the lives of women who divorce their husbands to relieve themselves of the situation. In addition, the suspicious attitude of the husband is also responsible for divorce by women. The constant suspicion that the husband has a relationship with the wife makes the wife's life unhappy, bad and miserable which hastens the divorce by the wife.

\subsection{Progress in women's education and economic freedom}

Divorce of women in Bangladesh is directly related to women's education and economic freedom. The participation of women in the workplace has increased because they are now more educated. Divorce rate are higher among educated husbands and wives. Earlier the divorce rate was higher among poor, illiterate, ignorant people but now it is increasing among all class of people in the country.

\subsection{Decision Making Power}

Women empowerment gives them decision making power. Women are free to taking any decision if they have enough power and wealth. As a result respect of others decision, adjust power also lost its appeal.

\subsection{Dominating Attitudes of Husband}

Both employed and unemployed women are face to dominating by husband. Women face excessive pressure by their husband with mentally and physically. They said:

When husband always dominating us mentally and physically sIt is no matter to us for enjoying religious festivals without few restrictions but in our own festivals we all participate, contribute economically and worship untidily.

\subsection{Breaking up Joint Family}

Breaking up a joint family and living a life of separation also involves women in making divorce decisions. Women both employed or unemployed want to living a nuclear family. They said:

Joint family where members are interrelated and living closely are sometimes painful. They cannot live freely because of many responsibility and bindings which make them always busy to do household activities.

\subsection{Availability of Social Media and TV Channels}

Because of availability of online dating applications and various social media including Facebook, WhatsApp, Imo, Messenger, etc., many spouses fall into extramarital affairs. Social medial connection is the main cause behind the rapid rise in divorce rates. Apart from this, various TV channels of other countries are also available in Bangladesh and women are also held accountable for increasing divorce.

\section{The effect of divorce}

Divorce has a serious impact on children and women in particular. As a result the high divorce rate by women in Bangladesh has received momentous attention. The effects of divorce are not the same for men and women but may be different. Every divorce can be stressful for personal life.

\subsection{Effect on Children}

Children are the primary victim of separation of their parents. Children from a broken family never receive the full parental care and love that is so essential to a child's mental growth and physical development. In most cases the children from broken families live without mother or in some cases without father. Divorce destroys children's lives. This divorce culture has destroyed family discipline and structure. One the other hand it destroys the future of the children.

\subsection{Effect on Divorced Women}

Although divorce sometimes creates opportunities for a woman to make a positive change in her life, in most cases she has to suffer unbearably. In the cultural and socio-economic context of Bangladesh, divorced women and their children are the most vulnerable in the society. Women are harassed by the society. It became impossible for her to survive in the society.

Women face many problems during their second marriage and as a result many women lose their mental balance. They said:

People inside and outside family treated us as a victim. They always talk about second marriage quickly otherwise we lost our chance to lead a family life. Even our parents feel uneasy to go outside and talking 
about us. Our income and education has not valued by the others in the society.

\subsection{Effects on the Family}

Divorce creates family quarrels. In the past Most of the cases family members does not welcome of their divorced daughter of sister. She does not want to divorce because their families will not give them shelter. But now a days the family also supports but after the divorce they suffer social pressure.

\subsection{Increasing Frustration}

One of the crucial effect of divorce is it increase frustration both people and society. Psychological pressure is exacerbating marital strife. Drug addiction and alcohol use also increasing in the society.

They said: One of the most harrowing life experiences is enduring divorce which leads to frustration, depression, increased anxiety, decreased physical strength and energy, performance, party confidence levels and they feel embarrassed and hopeless, restless and treat others badly.

\subsection{Social Disorder}

Family as a major social institution plays vital role for our life. Break down of a family bonding creates social disorder. By giving divorce, people are suffered economically, religiously and emotionally.

\section{Case Study \\ 7.1. Case One}

Sabiha Haque a 27 years divorced woman who has a daughter of 5 years old. After divorce she came to her parent's house with her daughter. Now she works in a NGO. She was married very early age in her parent's choice. Sabiha sharing her house with her parents and brothers families. Her monthly income is ten thousand tk. This is not enough to accommodate herself separately. Now her daughter going to school and it is difficult to bear study cost. She spends more than eight hours in her work and cannot take care her daughter. Sabiha's parents always create pressure to remarry and feel her as a burden. She divorced her husband two years ago because he tortured her physically. Her mother in law supports her husband to torture because she wants to dowry and giving birth boys. Sabiha always face inferiority complex in her five years conjugal life. After one years of marriage, she conceived and could not continue her study. After giving birth baby girl her mother in laws want to remarry her husband. Then always threat her and tortured physically and mentally seriously. Sabiha's family did not support to taking decision of divorce because they are not economically wealthy. But at a time, it was impossible to tolerate torture and finally she divorces her husband with the help of local NGOs and advocate. After divorce she faces social harassment and pressure for second time marriage. Now she confused about her daughter's life and wants to educate her properly.

\subsection{Case Two}

Sadhona Roy a 49 years women who lives with her son, working in a local factory. She was married at the age of 20 in a poor family. Her husband was a rickshaw puller. When she married him, Sadhona's family did not accept her husband. Sadhona left her parent's family then. After few days of marriage, she feels her husband was a drug addicted person. He was beating her anytime without any reason. Two years later she gave birth her sun but her husband was not change his behave. One day he wanted to kill Sadhona's baby as a drunker. She always feared of her baby and herself. He demanded money but Sadhona could not give it. When her baby was growing, he refused to take care of them and burnt her house. Then Sadhona went to local Government and took divorce her husband. Sadhona went to a shrimp factory few days. Now she left it because she stroked and paralyses one side. Her son going to factory and earn their livelihood but it is difficult to maintain family with small income.

\subsection{Case Three}

Marina Khan a dentist of a private clinic age of 30 years. She has a daughter of seven years age. She belongs to an economically wealthy family and only daughter of her parents. She married a businessman by her parent's choice. After marriage she felt her husband always suspicious of her. Marina's sister in law living with them and interfere their conjugal life. It was intolerable to Marina and she informed it her parents. They tried best to continue their family but Marina's husband was not changing his behavior. Then Marina divorced him and taking responsibility of her daughter. Now she feel her daughter always face shy to go outside home. Her daughter cannot adjust with other children of school. Marina's parent want to remarry her but she think it will be wrong with him in second time.

\section{Key Findings}

Divorce is a factor of insolence that applies on both men and women. A holy bond is utterly upset through divorce. Currently, almost everyone is going through a kind of social, economic and family stress due to the COVID-19 
pandemic. It has also increased intolerance among people. Divorce is on the rise due to family quarrels. In the past, women did not want to get divorced because their families did not want to give them shelter.

But nowadays, family member also support it. Husband and his family's behavior are one of the major causes of divorced by women. Besides this women empowerment, easy method and short time, social prestige, help by Government and Non-Government officials, political party's intervention also accelerate divorce by women. Divorced women both employed or unemployed at first threaten and tortured physically and mentally by husband and their family. When the problems going on regularly then they take decision about divorce. Most of the time they take their children's responsibility. After divorce women face social dishonor by their family, friends even work place. People think divorced woman has lack of adjusting power. For that they cannot continue their conjugal life. It is very simple to demand dowry to the bride house and husband's suspicious nature is found everywhere. Woman is responsible for divorce because she need to more patience to cope with a new environment is thinking by society. It is very challenging to lead a life of a woman after separation because our society are not treat respectfully of a divorced woman and her children.

\section{Conclusion}

Divorce in our country is a right of every citizen who has entered into a valid marriage contract. This sometimes becomes necessary because by exercising this right a woman gets a chance to make a positive change in her personal life from physical and mental abuse, a better career and a better environment and relief form mental abuse, depression and start her life again. The divorce rate in Bangladesh is increasing day by day due to various socioeconomic reasons. A growing trend of divorce means growing disruptions in family harmony, a painful experience and a source of serious trauma for children that can have a lifelong impact. Earlier most of the divorce applicants were men but now it has changed dramatically and about seventy percent of the total divorce applicants are women. Women's education is a major factor in their ability to make decisions based on their economic strength. On the other hand, violence against women and dowry are two major reasons behind seeking divorce in Bangladesh. Religious and moral values, social order and the positive intervention of significant people in society can prevent divorce. Marital life needs to be kept stress free. It is essential to create a kind of social pressure against divorce. The marital life survives on the self-sacrifice of both husband and wife. Couples should respect each other and family members also help maintain marital life.

\section{References}

Akter, S.2013. Effects of Family Break up of Children: A Study in Khulna City. Bangladesh e-journal of Sociology, 10(1):138-152

Abu Saleh, K. and Mitra. A. 2016. Trends and Patterns of Violence against Women in Bangladesh, Global Journal of Human Social-Science, 16(6): 28-34

Alam,N., Saha,S.k., Razaque, A., Ginneken, j.k.v. 2001.The Effect of Divorce on Infant Mortality in a Remote Area of Bangladesh, Journal of Biosocial Science, 33(2): 271-278

Amato, P.R, and Sobolewski, J.M. 2001. The Effects of Divorce and Marital Discord on Adult Children's Psychological Well-being, The American Sociological Review, 66(8): 900-919

Afroz, S. 2019. The Rise of Divorce in Bangladesh: A Review in the Change of Marriage Dynamics, Science Publishing Group,8(5): 261-269

AFS, 2021. Annual Fact Sheet of Divorce Rate, April, 2021. Prothom Alo

BBS, 2021. Bangladesh Bureaue of Statistics. A Statistical Report on Divorce Rate in Bangladesh. July, 2021.

BBS, 2020. Bangladesh Bureau of Statistics. A Statistical Report on Divorce Rate in Bangladesh, July, 2020.

Imam,S.H. 2020. Higher Incidence of Divorce, Financial Express, Dhaka, Bangladesh

Jahan,y., Chowdhury, A.s., Rahman, S.M.A. 2017. Factors Involving Extramarital Affairs in Bangladesh, International Journal of Community Medicine and Public Health, 4(5): 1379-1386

Kamaruzzaman, M.2015. Dowry Related Violence against Rural Women in Bangladesh, American Journal of Psychology and Cognitive Science, 1(4):112-116

Khanom, M. 2017. Increasing Divorce Rate and the Role of Economy, The Daily observer

Monsor, T. 2003. Dowry Problem in Bangladesh: Legal and Socio-cultural Perspectives, The Dhaka University Studies, 14(1): 1-16

Nowsen,N. 2021. Understanding the Rise in Divorce in Bangladesh. The Daily Star

Patoari, M.M.H. 2020. Socio-economic and Cultural Causes and Effects of Increasing Divorce Rate by Women in Bangladesh: ACritical Analysis. Asian Journal of Social Science Studies, 5(1):21

Rahman,M.M. and Akhter, M.T. 2013.The Social Sanction of Divorce: Who Ultimately Pay the Social Costs of its Adverse Effects?, Sociology and Anthropology,1(1): 26-33

Huda, Z.2021. Why Increasing Divorce Rate in Bangladesh during Covid-19 Pandemic. Kaler Kontho 